\title{
Gordonia caeni sp. nov., isolated from sludge of a sewage disposal plant
}

\author{
Sathiyaraj Srinivasan, ${ }^{1,2}$ Giho Park, ${ }^{3}$ Hyejin Yang, ${ }^{1}$ Supyong Hwang, ${ }^{1}$ \\ Yoonjung Bae, ${ }^{1}$ Yong-An Jung, ${ }^{4}$ Myung Kyum Kim ${ }^{1}$ and Myungjin Lee ${ }^{3}$ \\ ${ }^{1}$ Department of Bio \& Environmental Technology, Division of Environmental \& Life Science, \\ College of Natural Science, Seoul Women's University, 623 Hwarangno, Nowon-gu, \\ Seoul 139-774, Republic of Korea \\ ${ }^{2}$ Research and Development Division, H-Plus Eco Ltd, BVC no. 301, KRIBB, Eoeun-dong, \\ Yuseong-gu, Daejeon, 305-333, Republic of Korea \\ ${ }^{3}$ Daewoo Institute of Construction Technology, 60 Songjuk-dong, Jangan-gu, Suwon-si, \\ Gyeonggi-do 440-210, Republic of Korea \\ ${ }^{4}$ Korea Testing Certification, Chemical Industry Team, 587-10, Sinsa-Dong, Gangnam-Gu, Seoul, \\ Republic of Korea
}

Correspondence

Myungjin Lee

mgeneli@nate.com

\begin{abstract}
A Gram-stain-positive, strictly aerobic, short-rod-shaped, non-motile strain (designated $\mathrm{MJ} 32^{\top}$ ) was isolated from a sludge sample of the Daejeon sewage disposal plant in South Korea. A polyphasic approach was applied to study the taxonomic position of strain MJ32 ${ }^{\top}$. Strain MJ32 ${ }^{\top}$ showed highest $16 \mathrm{~S}$ rRNA gene sequence similarity to Gordonia hirsuta DSM $44140^{\top}(98.1 \%)$ and Gordonia hydrophobica DSM $44015^{\top}$ (97.0\%); levels of sequence similarity to the type strains of other recognized Gordonia species were less than $97.0 \%$. Phylogenetic analysis based on 16S rRNA gene sequences showed that strain $\mathrm{MJ} 2^{\top}$ belonged to the clade formed by members of the genus Gordonia in the family Gordoniaceae. The $\mathrm{G}+\mathrm{C}$ content of the genomic DNA of strain MJ32 ${ }^{\top}$ was 69.2 mol\%. Chemotaxonomically, strain $\mathrm{MJ}_{3} 2^{\top}$ showed features typical of the genus Gordonia. The predominant respiratory quinone was MK- $9\left(\mathrm{H}_{2}\right)$, the mycolic acids present had $\mathrm{C}_{56}-\mathrm{C}_{60}$ carbon atoms, and the major fatty acids were $\mathrm{C}_{16: 0}(34.6 \%)$, tuberculostearic acid (21.8\%), $\mathrm{C}_{16: 1} \omega 7 c(19.5 \%)$ and $\mathrm{C}_{18: 1} \omega 9 c(12.7 \%)$. The peptidoglycan type was based on meso-2,6-diaminopimelic acid as the diagnostic diamino acid with glycolated sugars. On the basis of phylogenetic inference, fatty acid profile and other phenotypic properties, strain $\mathrm{MJ}_{32}{ }^{\top}$ is considered to represent a novel species of the genus Gordonia, for which the name Gordonia caeni sp. nov. is proposed. The type strain is $\mathrm{MJ}_{3} 2^{\top}\left(=\mathrm{KCTC} 19771^{\top}=\mathrm{JCM}\right.$ $\left.16923^{T}\right)$.
\end{abstract}

The genus Gordonia (formerly Gordona) was proposed by Tsukamura (1971) to accommodate a mycolic acid-containing group of actinomycetes belonging to the family Gordoniaceae of the suborder Corynebacterineae (Stackebrandt et al., 1997; Goodfellow et al., 1998). Gordonia are Gram-positive, nonmotile short-rods to coccids, containing peptidoglycan of $\mathrm{A} 1 \gamma$ type with meso-diaminopimelic acid as the diamino acid and muramic acid with $N$-glycolyl residues often with arabinose and galactose or glucose as cell-wall sugars. Members of the genus Gordonia have been isolated from a variety of sources, such as clinical samples and various environmental sources

\footnotetext{
The GenBank/EMBL/DDBJ accession number for the 16S rRNA gene sequence of strain MJ32 ${ }^{\top}$ is JF806526.

A supplementary table and four supplementary figures are available with the online version of this paper.
}

including xenobiotic compounds and soil (Park et al., 2009; Kämpfer et al., 2010).

In the course of collecting micro-organisms from sludge at the Daejeon sewage disposal plant in South Korea, a Gramstain-positive, non-motile, aerobic, non-spore-forming strain, designated $\mathrm{MJ} 32^{\mathrm{T}}$, was isolated. On the basis of $16 \mathrm{~S}$ rRNA gene sequence analysis, strain $\mathrm{MJ} 32^{\mathrm{T}}$ was considered to belong to the genus Gordonia. It was subjected to a polyphasic taxonomic investigation and the results indicated that it represents a novel Gordonia species.

For isolation of strain $\mathrm{MJ} 32^{\mathrm{T}}, 1 \mathrm{~g}$ sludge sample was mixed with $50 \mathrm{ml}$ saline $(0.85 \% \mathrm{NaCl})$, vortexed and serially diluted; $100 \mu \mathrm{l}$ of each dilution was spread onto $0.1 \times \mathrm{R} 2 \mathrm{~A}$ agar (Difco) and incubated at $30{ }^{\circ} \mathrm{C}$ for 1 week. Single colonies of strain $\mathrm{MJ} 32^{\mathrm{T}}$ were transferred onto new plates and the purified colonies were tentatively identified by 
analysis of partial 16S rRNA gene sequences. The isolate was routinely cultured on nutrient agar (NA; Difco) at $30{ }^{\circ} \mathrm{C}$ and preserved as a suspension in Luria-Bertani (LB) broth (Difco) with $20 \%(\mathrm{w} / \mathrm{v})$ glycerol at $-70{ }^{\circ} \mathrm{C}$.

The genomic DNA of strain MJ32 ${ }^{\mathrm{T}}$ was extracted by using a commercial genomic DNA extraction kit (Solgent) and PCR-mediated amplification of the 16S rRNA gene and sequencing of the purified PCR product were carried out according to Kim et al. (2005). The nearly complete sequence of the 16S rRNA gene (1433 nt) was compiled with SeqMan software (DNASTAR). The 16S rRNA gene sequences of related taxa were obtained from GenBank and edited via the program BioEdit (Hall, 1999). Multiple alignments were performed with the program CLUSTAL $\mathrm{X}$ (Thompson et al., 1997). Evolutionary distances were calculated by using the Kimura two-parameter model (Kimura, 1983). A phylogenetic tree was constructed with the neighbour-joining (Saitou \& Nei, 1987) and maximumparsimony (Fitch, 1971) method in the program MEGA3 (Kumar et al., 2004) (Fig. 1). Bootstrap analyses, with 1000 replicates, were performed to obtain confidence levels for the branches (Felsenstein, 1985) and a maximum-likelihood tree was constructed by using the PHYLIP program (Fig. S1 in IJSEM Online) (Choi et al., 2000; Brinkman et al., 2001).

On the basis of 16S rRNA gene sequence similarity, the closest relatives of strain $\mathrm{MJ} 32^{\mathrm{T}}$ were Gordonia hirsuta DSM $44140^{\mathrm{T}}(98.1 \%)$ and Gordonia hydrophobica DSM $44015^{\mathrm{T}}$ (97.0\%). Levels of $16 \mathrm{~S}$ rRNA gene sequence similarity to the type strains of other Gordonia species were less than $97 \%$. Consequently, the type strains of Gordonia species were obtained and grown under the same conditions as strain $\mathrm{MJ} 32^{\mathrm{T}}$ and used as reference strains for phenotypic, chemotaxonomic and DNA hybridization experiments.

Cell morphology and motility were observed with an Olympus light microscope $(1000 \times$ magnification $)$ by using cells grown for $24 \mathrm{~h}$ in nutrient broth at $30{ }^{\circ} \mathrm{C}$. For electron microscopy, cells were gently resuspended in one drop of deionized $\mathrm{H}_{2} \mathrm{O}$, and samples were placed on carbon- and Formvar-coated nickel grids for $30 \mathrm{~s}$. Grids were floated on one drop of $0.1 \%(\mathrm{w} / \mathrm{v})$ aqueous uranyl acetate, blotted dry and then viewed with a Carl Zeiss LEO912AB electron microscope at $100 \mathrm{kV}$ under standard operating conditions. The Gram reaction was performed by

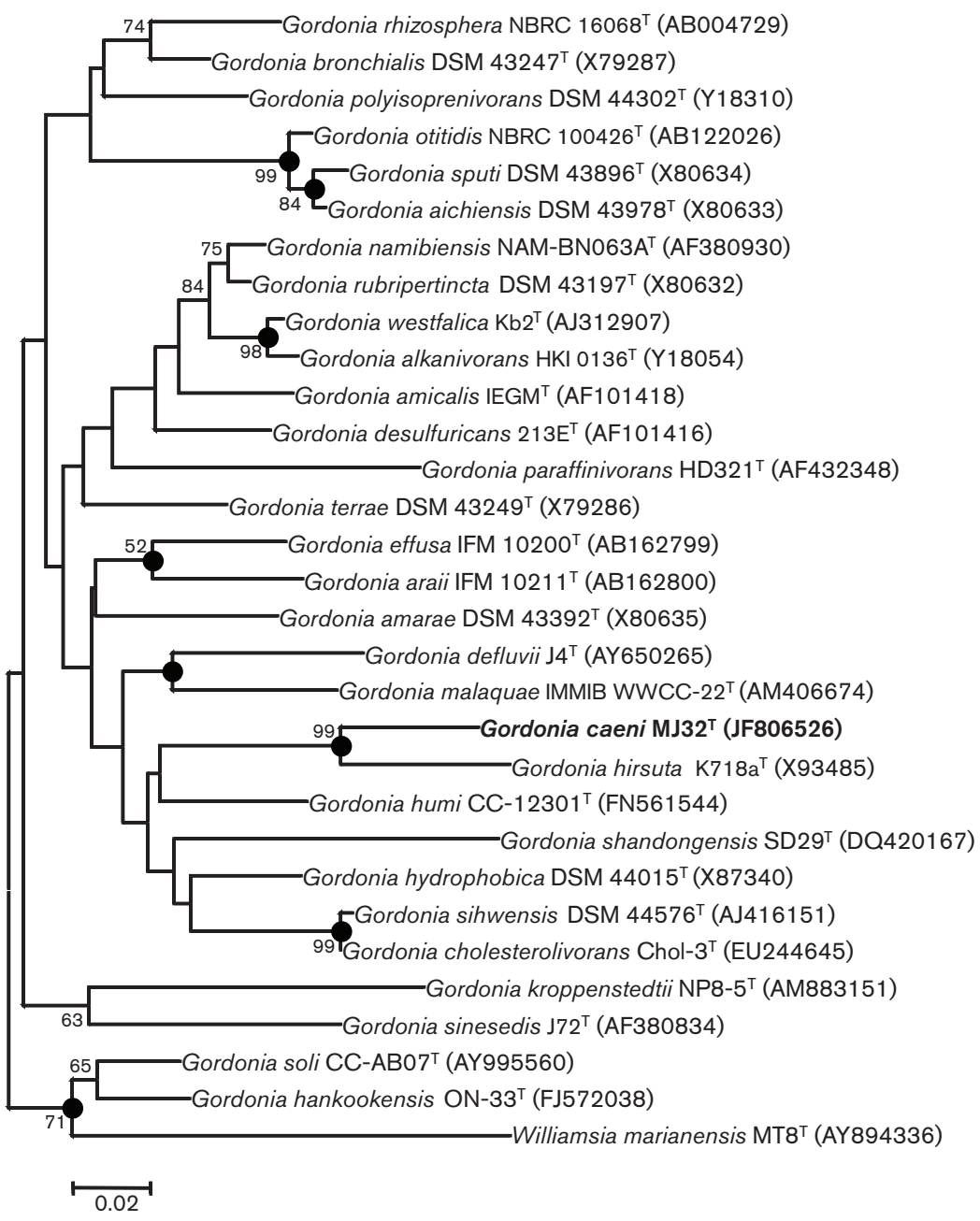

Fig. 1. Neighbour-joining phylogenetic tree based on 16S rRNA gene sequences, showing the relationships between strain $\mathrm{MJ} 32^{\top}$ and the type strains of recognized Gordonia species. Bootstrap values of $>50 \%$ (percentages of 1000 replications) are shown at branch points. Filled circles indicate that the corresponding nodes were also recovered in the tree generated with the maximum-parsimony algorithm. Bar, 0.02 substitutions per nucleotide position. Williamsia marianensis MT8 ${ }^{\top}$ was used as an outgroup. 
using the non-staining method, as described by Buck (1982). Catalase activity was assessed by bubble production in $3 \%(\mathrm{v} / \mathrm{v}) \mathrm{H}_{2} \mathrm{O}_{2}$ and oxidase activity was assessed by using $1 \%(\mathrm{w} / \mathrm{v})$ tetramethyl $p$-phenylenediamine (Cappuccino \& Sherman, 2002). Anaerobic growth was examined in serum bottles with sodium thioglycolate $\left(1 \mathrm{~g} \mathrm{l}^{-1}\right)$ added to nutrient broth and the upper air layer was replaced with nitrogen. Physiological characteristics were determined with API 20NE, API ID 32 GN and API ZYM galleries (bioMérieux) according to the manufacturer's instructions. Growth at 4, 10, 20, 25, 28, 30, 37, 40, 42 and $45^{\circ} \mathrm{C}$ and at $\mathrm{pH} 5.0-10.0(0.5 \mathrm{pH}$ unit intervals) was assessed in LB broth for 5 days. The $\mathrm{pH}$ of the medium was maintained via three buffers (final concentration $50 \mathrm{mM}$ ): acetate buffer (for $\mathrm{pH}$ 5.0-5.5), phosphate buffer (for $\mathrm{pH}$ 6.0-8.0) and Tris buffer (for $\mathrm{pH} 8.5-10.0$ ). Salt tolerance was tested in R2A broth supplemented with $0-10 \% \quad(\mathrm{w} / \mathrm{v}) \mathrm{NaCl}$ incubated for 5 days at $30{ }^{\circ} \mathrm{C}$. Degradation of DNA (DNase agar; Scharlau), casein, chitin, starch (Atlas, 1993), xylan and CM-cellulose (Ten et al., 2004) was also investigated; reactions were read after 5 days. Growth on trypticase soy agar (TSA; Difco), R2A agar and LB agar was also evaluated at $30^{\circ} \mathrm{C}$. The phenotypic characteristics of strain $\mathrm{MJ} 32^{\mathrm{T}}$ are given in the species description and those that differentiated strain $\mathrm{MJ} 32^{\mathrm{T}}$ from the type strains of closely related Gordonia species are listed in Table 1 . Strain $\mathrm{MJ}_{32}{ }^{\mathrm{T}}$ could be differentiated from G. hirsuta KCTC $9816^{\mathrm{T}}$, G. hydrophobica KCTC $9814^{\mathrm{T}}$ and Gordonia humi DSM $45298^{\mathrm{T}}$ based on the following characteristics: pale yellow colonies, positive for oxidase, esterase and $\beta$-galactosidase (PNPG), and assimilation of 2-ketogluconate $(\alpha)$, L-fucose, maltose and melibiose; colonies of G. hirsuta KCTC $9816^{\mathrm{T}}$ are light yellow and negative for oxidase.

For quinone, mycolic acid, polar lipid and peptidoglycan analysis, cells were grown aerobically on LB medium at $30{ }^{\circ} \mathrm{C}$. Isoprenoid quinones were extracted from bacterial cells of strain $\mathrm{MJ} 32^{\mathrm{T}}$ with chloroform/methanol $(2: 1, \mathrm{v} / \mathrm{v})$, evaporated under vacuum and re-extracted in $n$-hexane/ water $(1: 1, \mathrm{v} / \mathrm{v})$. The crude $\mathrm{n}$-hexane quinone solution was then purified by using silica Sep-Pak Vac cartridges (Waters) and subsequently analysed by HPLC, as described by Hiraishi et al. (1996). Strain $\mathrm{MJ} 32^{\mathrm{T}}$ contained menaquinone MK- $9\left(\mathrm{H}_{2}\right)$ as the major respiratory quinone and minor amounts of MK- $8\left(\mathrm{H}_{2}\right)$. The peptidoglycan was analysed as described by Schleifer \& Kandler (1972) by using TLC on cellulose sheets instead of paper chromatography. The murein acyl type was determined according to the colorimetric method of Uchida et al. (1999). Strain $\mathrm{MJ} 32^{\mathrm{T}}$ contained meso-2,6-diaminopimelic acid as the diamino acid. Whole-cell sugars contained arabinose and glucose, and sugars in the peptidoglycan were glycolated as is common for Gordonia species. Mycolic acids were extracted according to Minnikin et al. (1975), spotted on silica gel TLC plates, developed in petroleum ether (boiling point 60 $\left.80{ }^{\circ} \mathrm{C}\right) /$ acetone $(95: 5, \mathrm{v} / \mathrm{v})$ and detected by charring at $140{ }^{\circ} \mathrm{C}$ after spraying with ethanolic molybdophosphoric acid $(5 \%, w / v)$. The mycolic acids in strain $\mathrm{MJ} 32^{\mathrm{T}}$ were identical to those in the reference strains of G. humi and G. terrae, which had also been extracted and analysed along with those of strain MJ32 $2^{\mathrm{T}}$. Based on TLC (Fig. S2), strain $\mathrm{MJ} 32^{\mathrm{T}}$ possessed mycolic acids comprising $\mathrm{C}_{56}-\mathrm{C}_{60}$ carbon atoms, as with the reference strains (Kämpfer et al., 2010).

For analysis of fatty acid methyl esters, strain $\mathrm{MJ} 32^{\mathrm{T}}$ and the type strains of closely related species were grown on TSA and two loopfuls of bacterial cells were harvested from the third quadrant streak (according to recommendations for the MIDI Sherlock system) and subjected to saponification, methylation and extraction according to Kuykendall et al. (1988). The fatty acid methyl ester mixtures were separated by using the Sherlock Microbial Identification System (TSBA6; Sherlock Version 6.0; MIDI), analysed by GC (Hewlett Packard 6890) and identified according to the Microbial Identification software package (Sasser, 1990). The overall fatty acid composition of strain $\mathrm{MJ}^{\mathrm{T}}{ }^{\mathrm{T}}$ (Table 2) was very similar to those of recognized Gordonia species, and supported the affiliation of strain $\mathrm{MJ}^{\mathrm{T}}{ }^{\mathrm{T}}$ to the genus Gordonia. The major components were $\mathrm{C}_{16: 0}(34.6 \%)$, tuberculostearic acid $(21.8 \%), \mathrm{C}_{16: 1} \omega 7 c(19.5 \%)$ and $\mathrm{C}_{18: 1} \omega 9 c(12.7 \%)$. Minor amounts of $\mathrm{C}_{14: 0}(3.4 \%), \mathrm{C}_{15: 0}(2.5 \%), \mathrm{C}_{17: 1} \omega 9 c$ $(1.7 \%) \mathrm{C}_{16: 1} \omega 9 c(1.6 \%)$ and $\mathrm{C}_{18: 0}(1.2 \%)$ were also present. Strain $\mathrm{MJ} 32^{\mathrm{T}}$ contained a greater amount of $\mathrm{C}_{16: 1} \omega 7 c$ than the type strain of G. hirsuta and this component was absent in G. hydrophobica and G. humi. To determine the polar lipid profile of strain $\mathrm{MJ} 31^{\mathrm{T}}$, total cellular polar lipids were extracted and examined by twodimensional TLC (Minnikin et al., 1977).

Total lipids were observed after staining with $5 \%$ ethanolic molybdophosphoric acid and spots were detected by using different reagents (Fig. S3). The results showed that strain MJ $32^{\mathrm{T}}$ contained a major amount of diphosphatidylglycerol, moderate amounts of phosphatidylethanolamine and phosphatidylglycerol, and minor amounts of phosphatidylinositol and eight unknown lipids. The polar lipid profile of strain $\mathrm{MJ} 32^{\mathrm{T}}$ was similar to those of recognized Gordonia species (Stackebrandt et al., 1988; Kämpfer et al., 2010).

For determination of the DNA G $+\mathrm{C}$ content, genomic DNA was extracted as described above and enzymically degraded into nucleosides. The nucleosides were analysed by HPLC as described by Tamaoka \& Komagata (1984) and Mesbah et al. (1989). The DNA G+C content of strain $\mathrm{MJ} 32^{\mathrm{T}}$ was $69.2 \mathrm{~mol} \%$.

DNA-DNA hybridization was performed by using DNA reassociation kinetics as described by De Ley et al. (1970). Purified, sonicated genomic DNA (65 mg) from each strain was used according to the method of Gonzalez \& Saiz-Jimenez (2005). DNA-DNA hybridization between strain $\mathrm{MJ} 32^{\mathrm{T}}$ and the type strains of closely related Gordonia species (selected on the basis of $16 \mathrm{~S}$ rRNA gene sequence similarity) was performed. Mean $\Delta T_{\mathrm{m}}$ and 
Table 1. Differential physiological characteristics between strain $M J 32^{\top}$ and the type strains of closely related Gordonia species

Strains: 1 , MJ32 ${ }^{\mathrm{T}}$; 2, G. hirsuta KCTC $9816^{\mathrm{T}}$; 3, G. hydrophobica KCTC $9814^{\mathrm{T}} ; 4$, G. humi DSM $45298^{\mathrm{T}} ; 5$, G. alkanivorans KCTC $9951^{\mathrm{T}} ; 6$, G. amarae KCTC $9803^{\mathrm{T}} ; 7$, G. amicalis KCTC $9904^{\mathrm{T}} ; 8$, G.

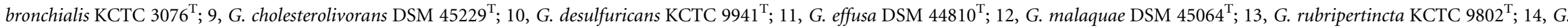
shandongensis DSM 45094 ${ }^{\mathrm{T}} ; 15$, G. sihwensis DSM $44576^{\mathrm{T}} ; 16$, G. terrae $\mathrm{KCTC} 9807^{\mathrm{T}} ; 17$, G. westfalica KCTC $9954^{\mathrm{T}}$. All data are from this study determined under the same experimental conditions. All strains are Gram-stain-positive non-motile bacteria that do not produce indole or acid from glucose. w, Weakly positive reaction.

\begin{tabular}{|c|c|c|c|c|c|c|c|c|c|c|c|c|c|c|c|c|c|}
\hline Characteristic & 1 & 2 & 3 & 4 & 5 & 6 & 7 & 8 & 9 & 10 & 11 & 12 & 13 & 14 & 15 & 16 & 17 \\
\hline Colony colour (LB) & Pale yellow & Light yellow & Tan & Pale yellow & Orange & Tan & Red & Orange & Beige & Pink & Light orange & Cream & Orange & Pale yellow & Tan & Red & Orange \\
\hline Oxidase & + & - & - & + & - & - & - & - & - & - & + & + & - & - & - & - & - \\
\hline Catalase & + & + & + & + & + & + & + & + & + & + & + & + & + & + & + & + & + \\
\hline \multicolumn{18}{|l|}{ Growth at/with (LB): } \\
\hline $20{ }^{\circ} \mathrm{C}$ & + & $\mathrm{w}$ & - & + & $\mathrm{W}$ & + & $\mathrm{w}$ & - & $\mathrm{w}$ & + & + & $\mathrm{w}$ & + & - & + & + & $\mathrm{w}$ \\
\hline pH 5 & $\mathrm{~W}$ & + & $\mathrm{W}$ & - & - & - & $\mathrm{w}$ & - & + & + & + & + & - & + & $\mathrm{w}$ & + & + \\
\hline $\mathrm{pH} 10$ & - & - & - & - & $\mathrm{W}$ & $\mathrm{W}$ & + & - & - & - & - & - & $\mathrm{w}$ & - & - & - & $\mathrm{w}$ \\
\hline $10 \% \mathrm{NaCl}$ & $\mathrm{W}$ & + & + & + & - & - & $\mathrm{w}$ & - & - & - & - & + & - & + & - & $\mathrm{W}$ & + \\
\hline \multicolumn{18}{|l|}{ Enzyme activity (API ZYM) } \\
\hline Cystine arylamidase & + & + & - & + & + & $\mathrm{w}$ & + & + & $\mathrm{w}$ & - & + & + & + & - & + & + & $\mathrm{w}$ \\
\hline Esterase (C4) & + & $\mathrm{w}$ & $\mathrm{w}$ & $\mathrm{W}$ & $\mathrm{W}$ & + & $\mathrm{W}$ & + & $\mathrm{w}$ & $\mathrm{W}$ & $\mathrm{w}$ & $\mathrm{w}$ & + & + & w & $\mathrm{W}$ & - \\
\hline Esterase (C8) & + & + & - & + & + & + & $\mathrm{w}$ & W & + & w & + & + & + & + & + & + & W \\
\hline$\alpha$-Fucosidase & - & - & - & + & - & - & - & - & - & - & - & - & - & $\mathrm{w}$ & $\mathrm{w}$ & - & - \\
\hline$\beta$-Galactosidase (ONPG) & - & - & - & - & - & - & $\mathrm{W}$ & - & $\mathrm{W}$ & + & + & + & - & + & + & - & - \\
\hline$\beta$-Galactosidase (PNPG) & + & - & $\mathrm{W}$ & - & - & - & + & + & $\mathrm{w}$ & + & + & + & - & + & + & - & - \\
\hline$\alpha$-Glucosidase (starch hydrolysis) & + & $\mathrm{w}$ & + & + & + & + & - & - & + & $\mathrm{w}$ & + & + & + & $\mathrm{w}$ & + & + & + \\
\hline $\begin{array}{l}\beta \text {-Glucosidase (aesculin } \\
\text { hydrolysis) }\end{array}$ & + & + & $\mathrm{w}$ & - & + & + & $\mathrm{w}$ & - & + & + & + & $\mathrm{w}$ & - & + & + & + & + \\
\hline$\beta$-Glucosidase & + & + & + & - & + & + & - & - & + & + & + & $\mathrm{w}$ & - & + & + & + & + \\
\hline Lipase (C14) & + & $\mathrm{w}$ & + & $\mathrm{w}$ & $\mathrm{w}$ & $\mathrm{w}$ & - & + & $\mathrm{w}$ & - & + & + & w & - & + & $\mathrm{w}$ & - \\
\hline $\begin{array}{l}\text { Naphthol-AS-BI- } \\
\text { phosphohydrolase }\end{array}$ & - & $\mathrm{w}$ & $\mathrm{w}$ & + & $\mathrm{W}$ & $\mathrm{w}$ & + & + & + & $\mathrm{w}$ & + & + & $\mathrm{w}$ & $\mathrm{W}$ & + & $\mathrm{W}$ & $\mathrm{w}$ \\
\hline Protease (gelatin hydrolysis) & $\mathrm{w}$ & - & - & - & - & - & - & - & - & + & - & - & - & + & - & - & + \\
\hline \multicolumn{18}{|l|}{ Assimilation (API ID 32GN) of: } \\
\hline 3-Hydroxybenzoate & - & - & + & + & - & - & - & - & - & - & - & - & - & - & - & - & - \\
\hline 2-Ketogluconate $(\alpha)$ & + & - & - & - & - & - & - & + & - & - & - & - & - & - & - & - & - \\
\hline Acetate & $\mathrm{w}$ & - & $\mathrm{w}$ & + & - & - & $\mathrm{w}$ & + & $\mathrm{w}$ & - & - & + & - & - & + & - & - \\
\hline Caprate & - & - & + & - & - & - & $\mathrm{w}$ & + & - & - & - & - & - & - & - & - & - \\
\hline Citrate & - & $\mathrm{w}$ & - & + & - & - & - & + & + & + & $\mathrm{w}$ & - & + & $\mathrm{W}$ & - & + & $\mathrm{w}$ \\
\hline Gluconate & + & - & + & $\mathrm{W}$ & + & W & $\mathrm{w}$ & + & - & + & $\mathrm{w}$ & + & + & + & - & $\mathrm{W}$ & + \\
\hline DL-Lactate & - & $\mathrm{w}$ & + & - & $\mathrm{W}$ & - & - & - & - & + & $\mathrm{w}$ & - & - & $\mathrm{W}$ & - & $\mathrm{W}$ & w \\
\hline L-Malate & + & - & + & + & + & - & - & + & + & + & + & $\mathrm{w}$ & w & $\mathrm{w}$ & + & + & + \\
\hline Propionate & - & - & + & + & - & - & + & + & w & - & - & - & $\mathrm{w}$ & - & $\mathrm{w}$ & - & - \\
\hline n-Valerate & - & - & + & + & - & w & $\mathrm{w}$ & - & $\mathrm{w}$ & $\mathrm{w}$ & $\mathrm{w}$ & - & w & - & + & - & - \\
\hline L-Arabinose & + & - & + & $\mathrm{w}$ & $\mathrm{w}$ & - & - & - & - & + & $\mathrm{w}$ & + & w & + & - & + & - \\
\hline L-Fucose & + & - & w & - & - & - & - & + & - & - & - & - & - & - & - & - & - \\
\hline
\end{tabular}




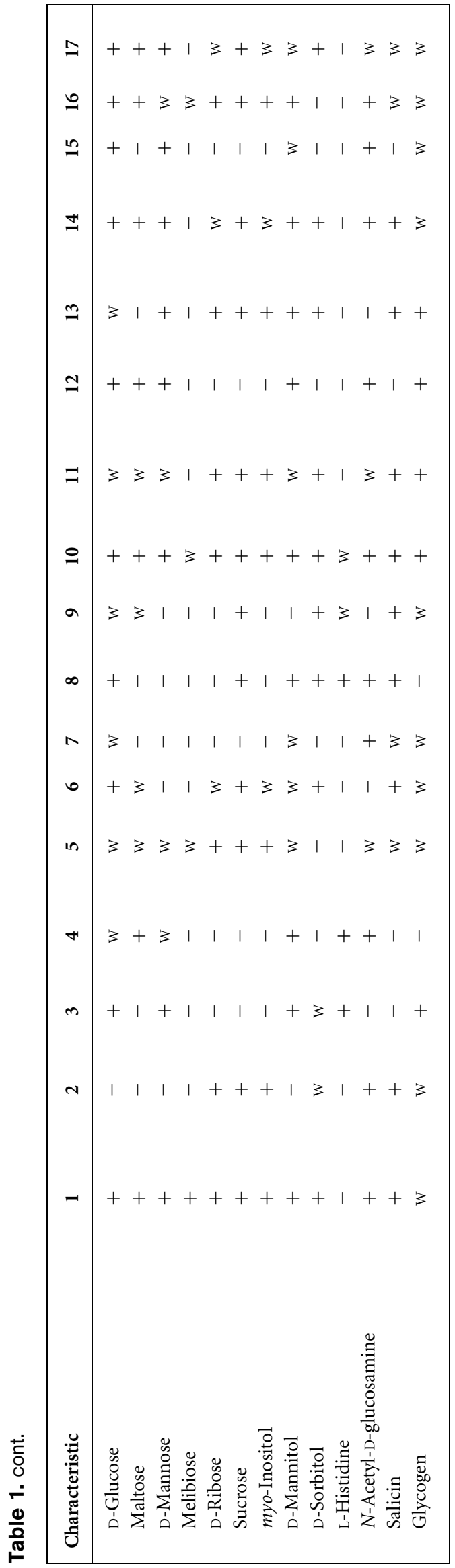

DNA-DNA relatedness values between strain $\mathrm{MJ} 32^{\mathrm{T}}$ and $G$. hirsuta KCTC $9816^{\mathrm{T}}$ were $8.1{ }^{\circ} \mathrm{C}$ and $47 \%(n=4)$ and between strain $\mathrm{MJ} 32^{\mathrm{T}}$ and G. hydrophobica KCTC $9814^{\mathrm{T}}$ were $10.8{ }^{\circ} \mathrm{C}$ and $36 \%(n=4)$. Levels of DNA-DNA relatedness between strain $\mathrm{MJ} 32^{\mathrm{T}}$ and the type strains of other closely related Gordonia species are given in Table S1. At the time of writing, $\Delta T_{\mathrm{m}}$ values of $5{ }^{\circ} \mathrm{C}$ and DNA-DNA relatedness values of less than $70 \%$, considered with phenotypic and chemotaxonomic differences, are acknowledged standards for the differentiation of bacterial species (Wayne et al., 1987; Stackebrandt et al., 2002).

The phenotypic and chemotaxonomic characteristics of strain MJ32 ${ }^{\mathrm{T}}$ were compared with those of closely related Gordonia species and the results are sufficient to differentiate it from its closest phylogenetic relatives. The results of the present polyphasic study indicate that strain $\mathrm{MJ} 32^{\mathrm{T}}$ represents a novel species of the genus Gordonia, for which the name Gordonia caeni sp. nov. is proposed.

\section{Description of Gordonia caeni sp. nov.}

Gordonia caeni (cae' ni. L. gen. n. caeni of sludge).

Cells are Gram-stain-positive, strictly aerobic, non-motile, non-spore-forming short rods, $0.2-0.3 \mu \mathrm{m}$ in diameter and $0.3-1.0 \mu \mathrm{m}$ in length (Fig. S4). After 3 days of incubation at $30{ }^{\circ} \mathrm{C}$ on R2A agar, colonies are $0.5-0.7 \mathrm{~mm}$ in diameter, pale yellow, smooth, convex and circular with regular edges. Growth occurs at $20-42{ }^{\circ} \mathrm{C}$ (optimum, $30{ }^{\circ} \mathrm{C}$; weak growth at $15{ }^{\circ} \mathrm{C}$ ). The $\mathrm{pH}$ range for growth is $\mathrm{pH} 6.0-9.5$ (optimum, pH 7.0-7.5). Growth occurs with $0-4 \%$ (w/v) $\mathrm{NaCl}$, but not with $11 \%$. Growth occurs on trypticase soy, LB, nutrient and R2A agars. Catalase- and oxidase-positive. Nitrate is reduced to nitrogen gas. Hydrolyses starch and casein but not chitin, CM-cellulose, DNA or xylan. In API ZYM and API 20E strips, positive for acid phosphatase, alkaline phosphatase, cystine arylamidase, esterase, esterase lipase, lipase, leucine arylamidase, $\alpha$-glucosidase and $\beta$ glucosidase activities; weak gelatinase and trypsin activities are also observed. Negative for arginine dihydrolase, $N$-acetyl- $\beta$-glucosaminidase, $\alpha$-chymotrypsin, naphtholAS-BI-phosphohydrolase, valine arylamidase, $\alpha$-fucosidase, $\alpha$-galactosidase, $\beta$-galactosidase, $\beta$-glucuronidase, $\alpha$-mannosidase and urease activities. In API ID32GN strips, assimilates $\mathrm{N}$-acetylglucosamine, L-arabinose, L-fucose, gluconate, D-glucose, L-malate, maltose, D-mannitol, melibiose, myo-inositol, potassium 2-ketogluconate, D-ribose, salicin, D-sorbitol and sucrose, and weakly assimilates adipate, Lalanine, citrate, glycogen, L-rhamnose and sodium acetate. Caprate, L-histidine, 3-hydroxybenzoic acid, 3-hydroxybutyric acid, 4-hydroxybenzoic acid, itaconate, DL-lactate, Dmannose, malonate, potassium 5-ketogluconate, phenylacetate, $\mathrm{L}$-proline, propionate, $\mathrm{n}$-valeric acid, $\mathrm{L}$-serine, suberate and sucrose are not assimilated. The predominant respiratory quinone is $\mathrm{MK}-9\left(\mathrm{H}_{2}\right)$. The polar lipid profile comprises diphosphatidylglycerol as the major component, with moderate amounts of phosphatidylethanolamine and phosphatidylglycerol. Mycolic acids are present. The 
Table 2. Fatty acid composition (\%) of strain $\mathrm{MJ}_{3} 2^{\top}$ and the type strains of closely related Gordonia species

Strains: 1, MJ32 ${ }^{\mathrm{T}}$; 2, G. hirsuta KCTC $9816^{\mathrm{T}}$; 3, G. hydrophobica KCTC $9814^{\mathrm{T}}$; 4, G. humi DSM 45298 ${ }^{\mathrm{T}}$; 5, G. alkanivorans KCTC 9951 ${ }^{\mathrm{T}}$; 6, G. amarae KCTC $9803^{\mathrm{T}}$; 7, G. amicalis KCTC $9904^{\mathrm{T}}$; 8, G. bronchialis KCTC $3076^{\mathrm{T}}$; 9, G. cholesterolivorans DSM 45229 ${ }^{\mathrm{T}}$; 10, G. desulfuricans $\mathrm{KCTC}$ $9941^{\mathrm{T}}$; 11, G. effusa DSM 44810 ${ }^{\mathrm{T}}$; 12, G. malaquae DSM 45064 ${ }^{\mathrm{T}}$; 13, G. rubripertincta KCTC $9802^{\mathrm{T}}$; 14, G. shandongensis DSM 45094 ${ }^{\mathrm{T}}$; 15 , G. sihwensis DSM $44576^{\mathrm{T}}$; 16 , G. terrae KCTC $9807^{\mathrm{T}}$; 17 , G. westfalica KCTC $9954^{\mathrm{T}}$. For unsaturated fatty acids, the position of the double bond is located by counting from the methyl $(\omega)$ end of the carbon chain. The cis isomers are indicated by the suffix $c$. Fatty acids amounting to $<1 \%$ of the total fatty acids are not shown. Tr, trace $(<1 \%)$; ND, not detected.

\begin{tabular}{|c|c|c|c|c|c|c|c|c|c|c|c|c|c|c|c|c|c|}
\hline Fatty acid & 1 & 2 & 3 & 4 & 5 & 6 & 7 & 8 & 9 & 10 & 11 & 12 & 13 & 14 & 15 & 16 & 17 \\
\hline $\mathrm{C}_{15: 0}$ & 2.5 & 1.1 & 5.1 & 2.1 & 2.8 & 1.3 & 3.1 & 2.4 & $\operatorname{Tr}$ & $\mathrm{ND}$ & 1.2 & 1.2 & 2.1 & 1.4 & 1.2 & 1.6 & 1.2 \\
\hline $\mathrm{C}_{16: 1} \omega 7 c$ & 19.5 & 1.2 & $\mathrm{ND}$ & $\mathrm{ND}$ & $\mathrm{ND}$ & 3.5 & 1.5 & 12.6 & 12.5 & 1.5 & 1.2 & 5.3 & $\mathrm{ND}$ & 3.2 & 1.2 & 1.3 & 1.2 \\
\hline $\mathrm{C}_{16: 1} \omega 9 c$ & 1.6 & 21.3 & 14.6 & 15.9 & 19.8 & 14.3 & 19.1 & 14.6 & 3.6 & 16.2 & 21.5 & 6.1 & 14.6 & 15.3 & 21.3 & 16.5 & 18.3 \\
\hline $\mathrm{C}_{16: 0}$ & 34.6 & 28.3 & 31.2 & 35.1 & 31.8 & 36.5 & 32.1 & 36.1 & 41.1 & 25.6 & 20.3 & 35.5 & 26.1 & 21.6 & 32.5 & 28.3 & 28.3 \\
\hline $\mathrm{C}_{17: 0}$ & $\mathrm{ND}$ & 1.3 & 3.5 & $\mathrm{ND}$ & 1.5 & 1.5 & 4.2 & 1.6 & 1.3 & 1.3 & 1.6 & 3.5 & 4.1 & 6.1 & 1.6 & 2.3 & 3.1 \\
\hline 10-methyl $C_{17: 0}$ & $\mathrm{ND}$ & $\mathrm{ND}$ & 5.1 & 2.3 & $\mathrm{ND}$ & 1.2 & 1.8 & $\mathrm{ND}$ & $\mathrm{ND}$ & $\mathrm{ND}$ & 1.3 & $\mathrm{ND}$ & 2.1 & 1.1 & $\mathrm{ND}$ & $\mathrm{ND}$ & ND \\
\hline $\mathrm{C}_{18: 1} \omega 9 c$ & 12.7 & 26.4 & 12.3 & 19.6 & 24.6 & 20.1 & 20.6 & 21.1 & 23.6 & 18.6 & 25.6 & 12.3 & 16.1 & 26.1 & 6.2 & 21.6 & 15.3 \\
\hline$C_{18: 0}$ & 1.2 & 1.3 & 1.6 & 1.6 & 1.2 & ND & 1.6 & 1.6 & 2.1 & 2.1 & 3.1 & 17.6 & 1.1 & 1.0 & 3.5 & 6.1 & 1.5 \\
\hline TBSA $^{*}$ & 21.8 & 15.6 & 20.1 & 18.7 & 12.2 & 16.1 & 6.5 & 1.7 & 13.4 & 32.5 & 21.2 & 16.5 & 26.1 & 20.3 & 26.9 & 17.2 & 28.1 \\
\hline
\end{tabular}

${ }^{\star}$ TBSA, tuberculostearic acid.

peptidoglycan type is based on meso-2,6-diaminopimelic acid as the diagnostic diamino acid. Glycolated cell-wall sugars such as arabinose and glucose are present in the cellwall peptidoglycan. The major fatty acids $(>12 \%)$ are $\mathrm{C}_{16: 0}$, tuberculostearic acid, $\mathrm{C}_{16: 1} \omega 7 c$ and $\mathrm{C}_{18: 1} \omega 9 c$; minor amounts of $\mathrm{C}_{14: 0}, \mathrm{C}_{15: 0}, \mathrm{C}_{17: 1} \omega 9 c, \mathrm{C}_{16: 1} \omega 9 c$ and $\mathrm{C}_{18: 0}$ are also present.

The type strain, MJ32 $2^{\mathrm{T}}\left(=\mathrm{KCTC} 19771^{\mathrm{T}}=\mathrm{JCM} 16923^{\mathrm{T}}\right)$, was isolated from sludge at the Daejeon sewage disposal plant in South Korea. The DNA G $+\mathrm{C}$ content of the type strain is $69.2 \mathrm{~mol} \%$ (HPLC).

\section{Acknowledgements}

This work was supported by the 21C Frontier Microbial Genomics and Application Center Program, Ministry of Science and Technology (grant MG08-0101-2-0), Republic of Korea.

\section{References}

Atlas, R. M. (1993). Handbook of Microbiological Media. Edited by L. C. Parks. Boca Raton, FL: CRC Press.

Brinkman, F. S., Wan, I., Hancock, R. E., Rose, A. M. \& Jones, S. J. (2001). PhyloBLAST: facilitating phylogenetic analysis of BLAST results. Bioinformatics 17, 385-387.

Buck, J. D. (1982). Nonstaining ( $\mathrm{KOH})$ method for determination of gram reactions of marine bacteria. Appl Environ Microbiol 44, 992993.

Cappuccino, J. G. \& Sherman, N. (2002). Microbiology: a Laboratory Manual, 6th edn. San Francisco: Benjamin Cummings.

Choi, J. H., Jung, H. Y., Kim, H. S. \& Cho, H. G. (2000). PhyloDraw: a phylogenetic tree drawing system. Bioinformatics 16, 1056-1058.
De Ley, J., Cattoir, H. \& Reynaerts, A. (1970). The quantitative measurement of DNA hybridization from renaturation rates. Eur $J$ Biochem 12, 133-142.

Felsenstein, J. (1985). Confidence limit on phylogenies: an approach using the bootstrap. Evolution 39, 783-791.

Fitch, W. M. (1971). Toward defining the course of evolution: minimum change for a specific tree topology. Syst Zool 20, 406-416.

Gonzalez, J. M. \& Saiz-Jimenez, C. (2005). A simple fluorimetric method for the estimation of DNA-DNA relatedness between closely related microorganisms by thermal denaturation temperatures. Extremophiles 9, 75-79.

Goodfellow, M., Alderson, G. \& Chun, J. (1998). Rhodococcal systematics: problems and developments. Antonie van Leeuwenhoek 74, 3-20.

Hall, T. A. (1999). BioEdit: a user-friendly biological sequence alignment editor and analysis program for Windows 95/98/NT. Nucleic Acids Symp Ser 41, 95-98.

Hiraishi, A., Ueda, Y., Ishihara, J. \& Mori, T. (1996). Comparative lipoquinone analysis of influent sewage and activated sludge by high performance liquid chromatography and photodiode array detection. J Gen Appl Microbiol 42, 457-469.

Kämpfer, P., Young, C. C., Chu, J. N., Frischmann, A., Busse, H. J., Arun, A. B., Shen, F. T. \& Rekha, P. D. (2010). Gordonia humi sp. nov., isolated from soil in Taiwan. Int J Syst Evol Microbiol 60, 824827

Kim, M. K., Im, W.-T., Ohta, H., Lee, M. \& Lee, S.-T. (2005). Sphingopyxis granuli sp. nov., a $\beta$-glucosidase-producing bacterium in the family Sphingomonadaceae in $\alpha-4$ subclass of the Proteobacteria. J Microbiol 43, 152-157.

Kimura, M. (1983). The Neutral Theory of Molecular Evolution. Cambridge: Cambridge University Press.

Kumar, S., Tamura, K. \& Nei, M. (2004). MEGA3: integrated software for molecular evolutionary genetics analysis and sequence alignment. Brief Bioinform 5, 150-163. 
Kuykendall, L. D., Roy, M. A., Neill, J. J. \& Devine, T. E. (1988). Fatty acids, antibiotic resistance and deoxyribonucleic acid homology groups of Bradyrhizobium japonicum. Int J Syst Bacteriol 38, 358-361.

Mesbah, M., Premachandran, U. \& Whitman, W. B. (1989). Precise measurement of the $\mathrm{G}+\mathrm{C}$ content of deoxyribonucleic acid by highperformance liquid chromatography. Int J Syst Bacteriol 39, 159-167.

Minnikin, D. E., Alshamaony, L. \& Goodfellow, M. (1975). Differentiation of Mycobacterium, Nocardia, and related taxa by thin-layer chromatographic analysis of whole-organism methanolysates. J Gen Microbiol 88, 200-204.

Minnikin, D. E., Patel, P. V., Alshamaony, L. \& Goodfellow, M. (1977). Polar lipid composition in the classification of Nocardia and related bacteria. Int J Syst Bacteriol 27, 104-117.

Park, S., Kang, S. J., Kim, W. \& Yoon, J. H. (2009). Gordonia hankookensis sp. nov., isolated from soil. Int J Syst Evol Microbiol 59, 3172-3175.

Saitou, N. \& Nei, M. (1987). The neighbor-joining method: a new method for reconstructing phylogenetic trees. Mol Biol Evol 4, 406-425.

Sasser, M. (1990). Identification of bacteria by gas chromatography of cellular fatty acids, Technical Note 101. Newark, DE: MIDI Inc.

Schleifer, K. H. \& Kandler, O. (1972). Peptidoglycan types of bacterial cell walls and their taxonomic implications. Bacteriol Rev 36, 407-477.

Stackebrandt, E., Smida, J. \& Collins, M. D. (1988). Evidence of phylogenetic heterogeneity within the genus Rhodococcus: revival of the genus Gordona (Tsukamura). J Gen Appl Microbiol 34, 341-348.

Stackebrandt, E., Rainey, F. A. \& Ward-Rainey, N. L. (1997). Proposal for a new hierarchic classification system, Actinobacteria classis nov. Int J Syst Bacteriol 47, 479-491.
Stackebrandt, E., Frederiksen, W., Garrity, G. M., Grimont, P. A., Kämpfer, P., Maiden, M. C., Nesme, X., Rosselló-Mora, R., Swings, J. $\&$ other authors (2002). Report of the ad hoc committee for the reevaluation of the species definition in bacteriology. Int J Syst Evol Microbiol 52, 1043-1047.

Tamaoka, J. \& Komagata, K. (1984). Determination of DNA base composition by reversed phase high-performance liquid chromatography. FEMS Microbiol Lett 25, 125-128.

Ten, L. N., Im, W.-T., Kim, M.-K., Kang, M. S. \& Lee, S.-T. (2004). Development of a plate technique for screening of polysaccharidedegrading microorganisms by using a mixture of insoluble chromogenic substrates. J Microbiol Methods 56, 375-382.

Thompson, J. D., Gibson, T. J., Plewniak, F., Jeanmougin, F. \& Higgins, D. G. (1997). The CLUSTAL_X windows interface: flexible strategies for multiple sequence alignment aided by quality analysis tools. Nucleic Acids Res 25, 4876-4882.

Tsukamura, M. (1971). Proposal of a new genus, Gordona, for slightly acid-fast organisms occurring in sputa of patients with pulmonary disease and in soil. J Gen Microbiol 68, 15-26.

Uchida, K., Kudo, T., Suzuki, K. I. \& Nakase, T. (1999). A new rapid method of glycolate test by diethyl ether extraction, which is applicable to a small amount of bacterial cells of less than one milligram. J Gen Appl Microbiol 45, 49-56.

Wayne, L. G., Brenner, D. J., Colwell, R. R., Grimont, P. A. D., Kandler, O., Krichevsky, M. I., Moore, L. H., Moore, W. E. C., Murray, R. G. E. \& other authors (1987). Report of the ad hoc committee on reconciliation of approaches to bacterial systematics. Int J Syst Bacteriol 37, 463464. 